УДК 343.121.5

\author{
Ю. П. Аленін, Д. В. Шилін
}

\title{
ЩОДО ПИТАННЯ ПРО ПРАВОВУ ПРИРОДУ ПРЕЮДИЦІЇ У КРИМІНАЛЬНОМУ ПРОЦЕСІ
}

Під час прийняття правозастосовних рішень, до яких належать і кримінальні процесуальні рішення, важливим етапом є встановлення фактичної основи справи, шо в межах кримінального процесу здійснюється шляхом доказування, тоб́то збирання, перевірки й оцінювання доказів.

У кримінальній процесуальній доказовій діяльності виникають такі правові ситуашії, коли певні обставини, які підягають доказуванню, уже встановлені в судовому рішенні в іншому процесі (цивільному, господарському, судово-адміністративному), рішенні в адміністративно-деліктному процесі або кримінальному процесуальному рішенні слідчого, прокурора, суду. У таких випадках виникає проблема преюдиції у кримінальному процесі.

Незважаючи на важливість преюдиції для забезпечення стабільності кримінальних процесуальних рішень та оптимізації процесу доказування, чинний Кримінальний процесуальний коЈекс України (далі КПК України) не згадує цього терміна, хоча ст. 128 КПК України містить норму щодо використання у кримінальному судочинстві рішення щодо позову.

У теорії кримінального процесу до проблеми преюдицій у кримінальному процесі зверталися такі вітчизняні й зарубіжні вчені, як А.М. Безруков, О.І. Бережний, В.В. Вапнярчук, О.Ю. Гай, Ю.М. Грошевий, О.В. Левченко, В.Т. Маляренко, Я.О. Мотовіловкер, І.Л. Петрухін, Г.М. Резнік, П.А. Скобліков, С.М. Стахівський, М.С. Строгович, Ф.Н. Фаткуллін, О.З. Хотинська, В.Д. Шундіков, У.М. Юсубова та ін.

Однак, незважаючи на наявні наукові дослідження преюдицій, залишилося багато невирішених питань шодо сутності преюдиції, її поняття $\mathrm{i}$ правової природи.

Тому метою статті $є$ дослідження правової природи преюдиції у кримінальному процесі й визначення шляхів удосконалення механізму використання преюдицій у кримінальному процесі. 
Характеристика правової природи преюдиції як явиша сучасного кримінального процесу не буде повною без короткого історичного аналізу тлумачення цього явиша.

Термін «преюдиція» римського походження, але вживався в римлян в іншому значенні, ніж сьогодні. Питання преюдишії більш докладно викладалися у праві Німеччини та Франції $[1$, с. $19-21 ; 2$, с. 49-51], а звідти це явище було рецепійовано до Росії та пристосовано до наявної правової практики. У Росії преюдиціальність розумілася як передсудимість у кримінальних справах. Так, згідно зі ст. 6 Статуту цивільного судочинства, позов про відшкодування шкоди чи збитку, заподіяних злочином чи провиною, міг бути поданий до цивільного суду «... не раніше ніж після закінчення кримінального провадження з того предмета, з якого позов виникає... [3].

у радянському процесуальному праві преюдиція набула зовсім іншого значення, ніж у дореволюційному праві. Преюдицією стали обтрунтовувати таке: а) під час прийняття рішень одним судом використання висновків іншого суду, зроблтених в іншому процесі; б) залежність вирішення деяких матеріально-правових питань кримінальної справи від попереднього рішення судового чи адміністративного органу [4, с. 21-22]. Це саме розуміння преюдиції, але в різних трактуваннях застосовується й сучасною процесуальною доктриною.

На сьогодні юристи по-різному тлумачать поняття преюдишіі.

А.В. Карданешь розглядає преюдицію як прийом юридичної техніки, шо являє собою правило доказування про те, що правозастосовне рішення уповноваженого органу, яке набрало законної сили, прийняте в установленому законом процесуальному порядку, про наявність або відсутність юридичного факту, обов'язкового для всіх правозастосовних органів, які вирішують юридичну справу, пов'язану із раніше вирішеною 3 приводу цього факту $[5$, с. 30$]$. Надаючи належне цьому визначенню преюдиції як прийому юридичної техніки, шо правильно вілображає iі правову природу, варто зазначити, що системний підхід до дослідження правових преюдишій дає змогу говорити про це явише як про загальноприйняте теоретичне положення, яке $є$ надбанням професійної правосвідомості й міститься в усіх компонентах правової системи.

Окремі вчені пропонують визначати поняття «преюдиція» як передсудимість (передрішення), сутність якої полягає в тому, що закон установлює визначене коло справ, які обов'язково передбачають попередній розгляд деяких пов'язаних із ними питань іншими органами й насамперед цивільними судами. Усі подібні постанови мають те значення, шо для суду, який розбирає справу, попереднє рішення іншого суду з питання, пов'язаного зі справою, що розглядається, має значення істини та приймається без будьяких доказів [6, с. 97]. Це поняття преюдиції походить із дореволюційного російського права. Тобто, за російським правом передсудимим у кримінальному процесі визнавалося правове питання, яке задовольняло б таким вимогам: предметом його повинні були бути обставини, шо обумовлюють наявність складу злочину; до вирішення цього питання був залучений ін- 
ший суд, а не суд, шо вирішує питання винуватості. Тому розуміння преюдиції як передсудимості повністю відповідає значенню цього інституту за дореволюційним російським правом, однак не відповідає ані розумінню преюдиції радянською доктриною, ані сучасною українською й російською кримінальною процесуальною наукою.

У радянській доктрині передрішення трактувалося дещо по-іншому. Так, даючи визначення передрішенню, Я.Л. Штутін зазначив, що передрішення в радянському цивільному процесі - це судовий вирок, судове рішення або постанова адміністративного органу із питання про наявність або відсутність юридичного факту або правовідношення, обов'язкові для суду, який вирішує справу, пов'язану із раніше вирішеною $[7$, с. 60].

Окремі вчені визначають преюдинію як певне правило, шо реалізується в доказуванні. Так, на думку Ю.М. Грошевого, преюдиції - це не засіб доказування фактів, а загальні положення / правила/, відповідно до яких особа, котра оцінює докази, і суд під час винесення вироку вправі вважати встановленими обставини, які мають значення для вирішення кримінальної справи [8, с. 254]. Існують й інші подібні визначення преюдиції. Так, B.В. Рясенцев відмічає, шо преюдиція - юридичне правило, згідно з яким рішення (вирок) одного суду, шо набрало законної сили, обов'язкове для іншого, а тому виключається повторний розглял однієї й тієї самої справи загалом або в частині $[9$, с. 23$]$.

Потрібно зазначити, шо все ж таки варто визначати преюдицію як правило, хоч і не можна повністю погодитися із тими його визначеннями, які наявні в літературі.

Отже, преюдиція - це доказове правило, що встановлює підстави й порядок використання в процесі доказування слідчим, прокурором, судом, суддею фактів і правових висновків, установлених такими, шо мають юридичну силу рішеннями слідчого, прокурора, суду, судлі у кримінальних, шивільних, господарських або адміністративних справах, якими справу вирішено по суті, як таких, шо не потребують повторного доведення.

Преюдиція має об'єктивні та суб'єктивні межі діï. Об'єктивні межі преюдиції окреслюють коло фактів, що установ.тені відповідним процесуальним актом і не підлягають у зв'язку з цим доказуванню. Суб'єктивні межі преюдиції визначають коло осіб, на які вона поширюється, у кримінальному процесі - тільки осіб, стосовно яких винесені відповідні акти.

Визначення преюдиції не буде повним без визначення ії галузевої правової природи. Так, потрібно зазначити, шо в тій чи іншій інтерпретації норми про преюдиції існують у всіх процесуальних кодексах. Так, відповідно до ст. $128 \mathrm{KПK} \mathrm{України,} \mathrm{відмова} \mathrm{в} \mathrm{позові} \mathrm{в} \mathrm{порядку} \mathrm{цивільного,} \mathrm{господар-}$ ського або адміністративного судочинства позбавляє цивільного позивача права висувати той самий позов у кримінальному провадженні. Також КПК України в ст. 90 встановлює, що рішення національного суду або міжнародної судової установи, яке набрало законної сили і яким установлено порушення прав людини й основоположних свобод, гарантованих Конституцією України та міжнародними договорами, згода на обов'язковість 
яких надана Верховною Радою України, має преюдиціальне значення для суду, шо вирішує питання про допустимість доказів [10]. Частина 4 ст. 61 ЦПК України [11] передбачає, що вирок у кримінальному провадженні, шо набрав законної сили, або постанова суду у справі про адміністративне правопорушення обов'язкові для суду, який розглядає справу про цивільно-правові наслідки дій особи, стосовно котрої ухвалено вирок або постанову суду, з питань, чи мали місце ці дії та чи вчинені вони цією особою. Норма ст. 72 Кодексу адміністративного судочинства України (далі - КАС України) [12] формулює як одну з підстав звільнення від доказування те, що вирок суду в кримінальному провадженні або постанова суду у справі про адміністративний проступок, які набрали законної сили, є обов'язковими для адміністративного суду, шо розглядає справу про правові наслідки дій чи бездіяльності особи, шодо котрої ухвалений вирок або постанова суду, лише в питаннях, чи мало місце діяння та чи вчинене воно цією особою. Вирок суду в кримінальному провадженні, що набрав законної сили, $є$ обов'язковим для господарського суду під час вирішення спору 3 питань, чи мали місце певні діï та ким вони вчинені (ст. 35 Господарського процесуального кодексу України [13]). Тобто, процесуальні норми містять інститут преюдиції в тому чи іншому ступені його досконалості. Тим самим досягається преюдиціальний взаємозв'язок між галузевими процесами для забезпечення несуперечливості й стабільності процесуальних рішень. Комплексність інституту преюдишії полягає в тому, шо він об'єднує норми інституту преюдиції у кримінальному процесуальному, цивільному процесуальному, господарському процесуальному та адміністративному процесуальному праві. Саме тому в літературі визнається двостороння дія судової преюдиції. Позитивна сторона преюдиції полягає у властивому рішенню суду імперативі (наказі), спрямованому суду та будь-яким іншим установам і особам, керуватися в іншому процесі або будь-якому іншому юрисдикційному акті, у якому підтверджені судовим рішенням факти $і$ правовідносини є фактичною підставою, раніше винесеним про ці факти та правовідносини рішення. Цей наказ випливає із формальної обов'язковості діiі рішення. Інша, негативна, сторона преюдиції полягає в недопустимості перегляду вказаних фактів і правовідносин у новому судовому процесі ги в порядку будь-якого іншого юрисдикційного розгляду. Вона випливає із законної сили рішення, тобто його незмінності, і має властиві законній силі суб'єктивні межі [14, с. 44-45].

Ураховуючи, шо інститут преюдиції $€$ комплексним правовим інститутом, необхідно розрізняти преюдицію у кримінальному процесі та кримінальну процесуальну преюдицію. Кримінальна процесуальна преюдишія $\epsilon$ доказовим правилом, що встановлює підстави й порядок використання в процесі доказування слідчим, прокурором, судом, суддею фактів і правових висновків, установлених такими, що мають юридичну силу рішеннями слідчого, прокурора, суду, судді у кримінальних справах, якими справу вирішено по суті, як таких, що не потребують повторного доведення. Преюдиція у кримінальному процесі включає в себе не тільки кримінальну 
процесуальну преюдицію, а й преюдицію судових рішень у цивільних, господарських та адміністративних справах при провадженні у кримінальній справі, а також рішень у справах про адміністративні правопорушення.

Підставами виникнення преюдиніі $\epsilon$ передусім взаємозв'язок справ. У кримінальному процесі про застосування преюдиції можна стверджувати в таких випадках:

- під час використання у справі щодо співучасника фактів і правових висновків, установлених у раніше винесеному рішенні щодо інших співучасників (тобто під час розгляду кримінальних справ, виділених в окреме провадження);

- під час використання у справі про давання завідомо неправдивих показань, завідомо неправдивого висновку фактів і правових висновків, установлених у раніше винесеному рішенні у справі, у межах якої давалися показання свідка або висновок експерта;

- під час використання у кримінальній справі при провадженні за нововиявленими обставинами тих рішень, якими ці об́ставини встановлено;

- під час використанні у кримінальній справі фактів і правових висновків, установлених у судовому рішенні в цивільній справі (наприклад, коли справа про відшкодування шкоди, завданої злочином, розглядалася в цивільному провадженні до розгляду кримінальної справи або у випалку необхілності наявності цивільної процесуальної преюдиції для кваліфікашіі діяння як злочину - ст. 164 Кримінального кодексу України тошо);

- під час використання у кримінальній справі фактів і правових висновків, установлених у судовому рішенні в господарській справі;

- під час використання у кримінальній справі фактів і правових висновків, установлених у правозастосовчому рішенні в аџміністративній справі (як у справі про адміністративне правопорушення, так і у справі в порядку КАС України);

- під час використання для прийняття процесуального рішення згідно з п. 6 ст. 284 КПК України.

Варто зазначити, що інколи в літературі заперечується преюдиціальне значення використання у справі щодо співучасника фактів і правових висновків, установлених у раніше винесеному рішенні щодо інших співучасників; використання у справі про давання завідомо неправдивих показань фактів і правових висновків, установлених у раніше винесеному рішенні у справі, у межах якої давалися показання свідка [4, с. 28]. Із цим важко погодитися. Якшо у кримінальному провадженні шодо співучасників установлено, шо мала місце подія злочину, склад злочину, то, якшо в суду не виникає сумнівів у вже винесеному вироку, він може застосувати встановлені факти та правові висновки як преюдиціальні. Дії співучасників, безумовно, пов'язані між собою, і справи, у межах яких дана оцінка цим діям, будуть пов'язані, а факти, установлені у справі, що раніше розглядалася, - преюдиціальними.

Преюдиція має важливе значення в межах кримінального процесу. Потрібно відзначити, шо питання про значення преюдиції $€$ спірним у доктри- 
ні. Окремі вчені вважають, шо преюдиція допускається з метою спрошення доказування [15 с. 147-149].

Деякі автори пов'язують значення преюдиції із забезпеченням «прошесуальної економіі» [1, с. 29]. На заперечення цього підхолу в літературі наводяться аргументи, шо процесуальній економії в цьому питанні не потрібно надавати головного значення. Процесуальну економію варто розцінювати як «побіжну» перевагу, яка досягається під час реалізації преюдицій, коли між преюдиціальними фактами й пов'язаними із ними матеріалами провадження в іншій кримінальній справі не виникає суперечностей.

На думку Є.В. Клінової, існують як мінімум дві мети, що повинні досягатися дією правила преюдиціальності. Першою метою $є$ забезпечення відповідності судових рішень одне одному, виключення суперечностей між ними. Другою метою діi преюдиції можна назвати полегшення сторонам можливості доказування фактів і правовідносин у наступних прошесах $[16$, c. 93$]$.

Як видається, під час визначення процесуального значення преюдиції потрібно розглядати цю проб́лему на макро- та мікрорівні. На мікрорівні, тобто на рівні конкретного провадження, значення преюдиції виявляється в полегшенні доказування, тобто використання без перевірки фактів і висновків, уже встановлених в інших провадженнях. На цьому самому рівні значення преюдиції полягає в досягненні процесуальної економіі. На макрорівні значення преюдишії потрібно розглядати для процесуального забезпечення діяльності правозастосовних органів. На цьому рівні значення преюдиції виявляється в забезпеченні стабільності процесуальних рішень, у тому числі судових. Крім того, аналіз значення преюдиції на макрорівні дає змогу стверджувати, шо використання преюдиції забезпечує несуперечливість процесуальних рішень. Загалом на макрорівні значення преюдиції можна розгяядати як забезпечення належного винесення законних і обгрунтованих процесуальних рішень.

\section{Література}

1. Бережний О.І. Преюдиціальність судових рішень у криміна.]ьних справах : дис. ... канд. юрид. наук : спец. 12.00 .09 «Криміна.льний процес та криміналістика; судова експертиза»/ O.I. Бережний. - Х., 2003. -191 c.

2. Фойницкий И.Я. Курс уголовного судопронзводства : в 2 т. / И.Я. Фойницкий. - СПб. : Aльфа, 1996. - T. 2. - 1996. - 607 c.

3. Устав гражданского судопроизводства / под ред. В.В. Исаченко. - СПб. : Право, 1911.

4. Юсубова У.М. Преюднцин в советском уголовном процессе : дисс. ... докт. юрнд. наук : спец. 12.00 .09 «Уголовный процесс; крнмнналнстика; судебная экспертиза» / У.М. Ксубова. - M., 1979. -225 c.

5. Карданец А.В. Преюдиции в российском праве. Проблемы теории и практики: дисс. ... канд. юрид. наук : спец. 12.00.01 «Теория и история государства и права: история политических и правсвых учений» / А.В. Карданец. - Нижний Новгород, 2002. - 181 с.

6. Арсеньев В.Д. О фактах. не подлежащих доказыванию в процессе уголовного судопроизводства / В.Д. Арсеньев / / Правоведение. - 1965. - № 1. - С. 97-104.

7. Штутин Я.Л. Предрешения (преюдиции) в советском гражданском процессе / Я.Л.Штутин / / Советское государство и право. - 1956. - № 5. - С. 58-67. 
8. Грошевой К.М. Теоретические проблемы формирования убеждения судьи в советском уголовном судопроизводстве : дисс.... докт. юрид. наук : спец. 12.00 .08 « Головное право и крнмннология; уголовно-исполнительное право» / К.М. Грошевой. - Х., 1975. - 403 с.

9. Рясенцев В. Вопросы преюдицин при рассмотренин судамн гражданских дел / В. Рясенцев // Советская юстиция. - 1985. - № 10. - С. 23-25.

10. Кримінальний процесуальний кодекс України від 13 квітня 2012 р. № 4651-VI |Електронний pecypcl. - Режим доступу : http://zakon4.rada.gov.ua/laws/show/4651-17.

11. Цивільний процесуальний кодекс Українн від 18 березня 2004 р. / / Відомості Верховної Ради України. - 2004. - № № 40-41, 42. - Ст. 492.

12. Кодекс адміністративного судочинства України від 06 лилня 2005 р. / / Відомості Верховної Ради України. - 2005. - № № 35-36. No 37. - Ст. 446.

13. Господарський процесуальний кодекс України від 06 листопада 1991 р. // Відомості Верховної Ради Уираїни. - 1992. - 느 6. - Ст. 56.

14. Гурвнц М.А. Обязательность и законная снла судебного решения / М.А. Гурвнч // Советское государство и право. - 1970. - Jo 5. - С. 37-45.

15. Теория доказательств в советском уголовном процессе / под ред. Н.В. Жогина. - М. : Юрид. лит., 1973. - 732 с.

16. Клинова Е.В. О преюдициальности судебного решения / Е.В. Клинова // Вестник Московского уннверснтета. Серня 11 «Право». - 2003. - oㅡ 6. - С. 91-98.

\section{A н о т а ц я я}

Arextк Ю. П., Шилік Д. В. Щодо питання про правову природу преюдиції у кримінальному процесі. - Стаття.

Стаття присвячена визначенню правової природи преюдиції як явиша сучасного кримінального процесу, шляхів удосконалення механізму використання преюдиції у кримінальному процесі. Досліджусться й обірунтовусться питання про те, що інститут преюднції с комплексним правовим інститутом.

Клюнияі слова: преюдиція, доказування у кримінальному процесі, преюдиціальність.

\section{А н но т а ция я}

Агекин Ю. П., ПІилик Д. В. Относительно вопроса о правовой природе преюдиции в уголовном процессе. - Статья.

Статья посвящена определению правовой природы преюдиции как явления современного уголовного процесса, путей усовершенствования механизма нспользования преюдиции в уголовном процессе. Исследуется и обосновывается тезис о том, что институт преюдиции является комплексным правовым институтом.

Kat)невие cлова: преюдиция, доказывание в уголовном процессе, преюдициальность.

\section{S u in in a r y}

Alenin Y.P., Shilin D. V. On the question of the legal nature of preclusion in criminal proceedings. - Article.

The article is devoted to the definition of the legal nature of preclusion as a phenomenon of the contemporary criminal proceedings and to the definition the ways to improve the mechanism of applying preclusion in criminal proceedings as well. The issue of whether the preclusion is complex legal institution is investigated and proved.

Key words: prejudice, proving in criminal proceedings, prejudicialness. 